\title{
Students' Attitudes Towards Learning, A Study on Their Academic Achievement and Internet Addiction
}

\author{
Meral, Sert Ağır ${ }^{1, *}$ \\ ${ }^{1}$ Education Sciences Department, Ataturk Education Faculty, Marmara University, Istanbul, Turkey \\ *Correspondence: Education Sciences Department, Ataturk Education Faculty, Marmara University, Istanbul, \\ Turkey. E-mail: meralagir@marmara.edu.tr
}

Received: July 24, 2019

doi:10.5430/wje.v9n4p109
Accepted: August 22, 2019 Online Published: August 25, 2019

URL: https://doi.org/10.5430/wje.v9n4p109

\begin{abstract}
Examining attitudes of students towards learning, their academic achievements and internet addictions is the main focus of this study. With the institution permission obtained from the Provincial Directorate of National Education of İstanbul Governorship dated: 21.04.2016 and No: 59090411-20-E.4519158, a descriptive study in relational screening model was conducted. By evaluating the data of 355 students (158 male and 176 female), from 370 students studying in the 9th, 10th, and 11th grades attending public high schools in the region of Kadıköy, İstanbul during 2015-2016 academic year the outcome results were obtained. "Personal Information Form", "Attitudes Towards Learning" and "Computer Addiction for Adolescents" scales were used in order to collect research data. By analyzing the data with $t$ test, one-way variance analysis (ANOVA) and correlation statistical research techniques in the SPSS 22.0 program, findings were obtained. A significance level of 0.05 was taken as the basis in the applied statistics. As per the findings, a difference was found in terms of internet addiction according to gender, academic achievement, homework habits, family activity frequency variables. Furthermore, a negative relationship was found according to the correlation analysis result between students' attitudes towards learning and internet addiction. In conclusion, in the light of the the research findings, it is possible to express that differentiation of students' attitudes towards learning can support effective and efficient use of information technologies. However, the negative differentiation of the attitudes towards learning can generate Internet addiction as a result of inefficient use of the information technologies.
\end{abstract}

Kewords: attitudes towards learning, internet addiction, academic achievement

\section{Introduction}

Technology is the product of the reflection of learning competence, which is one of the basic characteristics of human beings, on the problem solving process. Technology, which has gradually transformed human beings into an information society, and perhaps will transform them into a society beyond their current imaginations, has become the precursors of change and development with its equivalent in the information society. Therefore, rapidly generation and dissemination of information necessitated the differentiation of the human model that the societies needed. It is necessary for this new human being to be aware of what information is meaningful to him in order to define his needs and produce behaviour change in this direction and to be self-directed to achieve his goals. Although this understanding may seem familiar to us as a phenomenon that has brought humanity to these days, the basic tool that drives the information society, considering the speed of development of information technologies and the area of influence, it is obvious that the education understanding that will support the new human model should be very different (Isman \& Gungoren, 2013). In other words, the definition and meaning of learning has changed in the information society.

In the last decade, especially in an era of rapid development of mobile communication technologies and devices, the characteristics of the people required by the societies have evolved; in order to adapt to the rapidly changing and developing world, communities require individuals who know how to access knowledge, who can use their knowledge when necessary and who are able to produce new information. Therefore, countries are more careful about their education systems and make investments accordingly (Scardamalia \& Bereiter, 1994; Castells, 1997; Akolaş, 2004; Atasoy, 2007; Van Merriënboer \& Brand-Gruwel, 2005; Stalder, 2006; Buabeng-Andoh, 2012). In the 
information society, the definition of learning and its meaning for an individual has changed (Castells, 2011). According to Alvin Toffler's statement, "The illiterate of the future will not be the uneducated one. It will be the one who does not know how to learn" (Toffler, 1981). In this context, the main aim of student-centered teaching activities focuses not on "what to teach" but rather "to teach how to learn". In regard to supporting this process, the relevant literature highlights that without integrating rapidly evolving information technologies into the teaching process, efforts for regulating educational contents, educational activities and educational settings may be incomplete and inadequate (Ağır, 2007; Duit \& Treagust, 2003; Kocacık, 2003; Reis, 2007; Castells, 2013).

Teaching supported by information technologies is very different to traditional education (Ağır, 2014; Drennan, Kennedy, \& Pisarski, 2005; Yılmaz \& Horzum, 2005; Deperlioğlu \& Köse, 2010, Wu, 2013). The most striking difference is that the instructor and the learner in other words "the teacher and the student" continuously bears the title "the learner" (Kettanurak, Ramamurthy, \& Haseman, 2001; Seferoğlu, 2004). As the traditional role of the teacher in the class disappears, teaching strategies, methods and techniques that will ensure the participation of all students in the classroom with different qualifications and interests can be easily applied (Ağır \& Bayraktar, 2011; Hong, Ridzuan, \& Kuek, 2003). Moreover, it is noted that it facilitates access to rich and diverse sources of information, enables the mental energy to be actively used in the most proper way possible as a result of feeling less physical fatigue for the teacher and the students (Baltacı \& Akpınar, 2011; Rahimi \& Yadollahi, 2011). Moreover, it provides a cost-effective way for testing of a case or an event of which accessibility, applicability and trialability is difficult, dangerous or impossible in life. (Iş̧1k, 2010; Kim, Choi, Kang, \& Kim, 2011).

The increasing use of information technologies both in teaching and everyday life has brought different problems needing to be solved along with it. Contrary to the expectations, different tendencies and attitudes in student behaviors during the teaching process have emerged. These problematic attitudes depending on the intended use of information technologies that affect the individuals' lives in addition to the lives of students have been categorized in relevant literature as "addictions" in the form of "virtual environment, game, internet, etc." (Young, 1998; Cole \& Griffiths, 2007; Kim, LaRose, \& Peng, 2009; Mehroof \& Griffiths, 2010; Üner \& Tanıdır, 2011; Günüç \& Kayri, 2013; Griffiths, Kuss, Billieux, \& Pontes, 2016). In other words, the problem has led to the need of considering the different dynamics that affect learning about "human" or "student" characteristics in the teaching process.

Even though the literature on education and teaching discusses factors affecting learning in a multidimensional way in order to realize teaching objectives, it is observed that teachers, performing the teaching, and parents both share the same focal point: attitudes of students towards learning. To put it in other words, the fundamental reason that teaching objectives have not been achieved are due to the attitudes of the students towards learning (Glynn, Aultman, \& Owens, 2005). The point that administrators, the teachers and the families responsible for the teaching activities draw attention to is "Behaviors to be produced in relation to the acquisition of certain behaviors (observable as performance)". Anything that "cannot be learned" by an individual is considered to be contrary to the human nature. Due to the fact that learning is a function of intelligence, it is the working mind that has carried the primitive human to what he is today, generating change and development and separating human beings from other living things. For this reason, except for certain special cases, it not possible to state the fact that a student cannot learn. Thus, it has been proven that attitudes as the total of emotional and behavioral tendencies and thoughts developed depending on several factors affect the acquisition of teaching objectives.

The concept of attitude is generally explained as positive or negative emotions and thoughts related to a specific social object such as humans, objects, facts or events (Bilgin, 2007). Attitude is a state of mental or neural readiness both as the premise and the consequences of behavior as a result of tendencies of emotions, thoughts, behaviors emerged due to previous experiences (Allport, 1967, Fishbein; 1967, Richardon, 1996) While attitudes, which are not directly seen but can be observed through behaviors, give direction to human behaviors, they are a phenomenon that can differentiate decision making, problem solving processes, in other words all interactions, and that can lead to bias. In other words, just as a positive response in a situation with a positive attitude can affect the approach to the events and phenomenon differently, negative reaction with a negative attitude can affect differently as well (Greenwald, 1968; Fazio, 1986; Tinkham, 1989; Ajzen \& Fishbein, 1977; Olson \& Zanna,1993; Ajzen \& Fishbein, 2005). Therefore, the effort of the student to show the expected behaviors in terms of teaching objectives, as a positive or negative attitude towards learning, is regarded as a predictor of the academic success of the student (Williams, 1992; Richardson, 1996; Osborne, Simon, \& Collins, 2003; Hong-sheng, 2005; Tandogan \& Orhan, 2007; McAuley, Leskovec, \& Jurafsky, 2012). A student displays feelings and thoughts in terms of learning environment and learning processes with appropriate or inappropriate behaviors in accordance with the expectations of the environment. He or she tends to explain ones' self with positive or negative attitudes. 
In this context, it is believed that there should be difference between the learning attitudes of students who have different behavioral tendencies and can experience problems by using information technologies other than their teaching objectives and the attitudes of students using this technology towards their learning objectives. Based on this idea, this study was conducted in order to support the studies regarding the fact that the unexpected effect of information technologies can be overcome by the difference that can be created in learning attitudes. Thus, as the technology can contribute to the expected positive effect, it has been thought that information about what might be the dynamics that influence learning attitudes of students can be obtained. Accordingly, the study has revealed whether students' attitudes towards learning, academic achievements form differences in their use other than computer learning. The main purpose of the study is to investigate whether there is a relationship between students' attitudes towards learning, academic success and internet addiction. In line with this main purpose, the research was conducted to answer the questions regarding if there is a difference in the dependent variables of internet addiction and learning attitude with respect to the independent variables of gender, students' perceived academic success level, time spent for homework in a week, time spent with their families, time spent for internet games and the internet connection in their homes.

\section{Method}

Relational screening model, the method attempting to examine the existing situation between two or more variables relationally, was the basis of this study (Karasar, 2014).

\subsection{The Study Group}

The study was conducted in the public schools at the high school level in Kadıköy district of Istanbul in the 2015-2016 academic year with the randomly selected students, from the schools who enrolled students with scores between 450 and 500 points out of 500 in the exams conducted during the transition from secondary education to high school, with the institutional permission provided by the Governorship of İstanbul Provincial Directorate of National Education, with the date 04.21.2016 and issue: 59090411-20-E.4519158. These schools are also considered as the schools that provide the highest number of students to the universities that accept students with high points/upper percentage points in transition to higher education. The 12th grade of the schools in which the research was carried out was excluded from the scope of the study with the joint decision of both the researcher and the school administrations as they were preparing for the transition exam to higher education. 370 students from 9th, 10th and 11th grades selected randomly participated in the study and the information of 335 students, 158 of who were 177 and female were evaluated.

\subsection{Data Collection Tools}

In order to measure students' attitudes towards learning, Learning Attitude scale was used. The Internet Addiction scale was used in order to measure Internet addiction and in order to obtain the demographic information of the students the personal information form prepared by the researcher was used.

\subsubsection{Learning Attitude Scale}

Developed by Kara (2010), learning attitude scale was prepared as a five-point Likert type consisting of 40 questions and four sub-dimensions. The Cronbach Alpha internal consistency coefficient of the scale was calculated as .73 and the test retest correlation coefficient was found to be .87 . According to the factor analysis for the study group the Cronbach Alpha value of the study was found to be .775 .

\subsubsection{Computer Addiction Scale}

Developed by Ayas, Çakır and Horzum (2011), the computer addiction scale consists of two factors; game and internet addictions. The game addiction factor consists of 26 and the internet addiction factor consists of 28 questions. The load value of the Internet addiction factor of the scale varies between .512 - 795 and accounts for $29.49 \%$ of the total variance of the scale. The game value of the Internet addiction factor of the scale varies between $424-.788$ and is accountable for $19.13 \%$ of the variance of the scale. The Internet addiction factor group of this study was used as the data collection tool for the study group and Cronbach Alpha value was found to be .952 according to the factor analysis performed.

\subsection{Sampling Procedures}

In this study, the demographic variables of the students were determined as the average time spent on gender, school achievement, and activities performed after school (doing homework, doing family activities, playing computer games). By analyzing the data with $t$ test, one-way variance analysis (ANOVA) and correlation statistical research 
techniques in the SPSS 22.0 program, the findings were obtained. In the applied statistics, a significance level of .05 was taken as basis.

\subsection{Data Analysis Process}

In this study, the demographic variables of the students were determined as the average time spent on gender, school achievement, and activities performed after school (doing homework, doing family activities, playing computer games). By analyzing the data with $t$ test, one-way variance analysis (ANOVA) and correlation statistical research techniques in the SPSS 22.0 program, the findings were obtained. In the applied statistics, a significance level of .05 was taken as basis.

\section{Results}

$9^{\text {th }}$ graders consisted $16.1 \%$ of participating students in the research, 10 th graders $33.7 \%$ and 11 th graders $50.1 \%$ (See Table 1).

Table 1. Demographic Characteristics of Students

\begin{tabular}{ccccccccc}
\hline Gender & $\mathrm{f}$ & $\%$ & Age & $\mathrm{f}$ & $\%$ & Grade & $\mathrm{f}$ & $\%$ \\
\hline Female & 158 & 47.2 & 15 & 37 & 11.0 & $9^{\text {th }}$ grade & 54 & 16.1 \\
Male & 177 & 52.8 & 16 & 154 & 46.0 & $10^{\text {th }}$ grade & 113 & 33.7 \\
Total & 335 & 100.0 & 17 & 144 & 43.0 & $11^{\text {th }}$ grade & 168 & 50.1 \\
& & & Total & 335 & 100.00 & Total & 355 & 100.0 \\
\hline
\end{tabular}

Table 2. Information on Demographic Characteristics of the Parents of Students

\begin{tabular}{|c|c|c|c|c|c|c|c|c|c|c|c|}
\hline \multirow[t]{2}{*}{$\begin{array}{l}\text { Level of } \\
\text { education }\end{array}$} & \multicolumn{2}{|c|}{ No education } & \multicolumn{2}{|c|}{$\begin{array}{c}\text { Primary } \\
\text { school }\end{array}$} & \multicolumn{2}{|c|}{$\begin{array}{c}\text { Secondary } \\
\text { school }\end{array}$} & \multicolumn{2}{|c|}{ High School } & \multicolumn{2}{|c|}{ University } & \multirow{2}{*}{$\begin{array}{r}\text { Total } \\
\mathrm{f} / \% \\
\end{array}$} \\
\hline & $f$ & $\%$ & $\mathrm{f}$ & $\%$ & $\mathrm{f}$ & $\%$ & $\mathrm{f}$ & $\%$ & $f$ & $\%$ & \\
\hline Mother & 6 & 1.8 & 43 & 12.8 & 43 & 12.8 & 119 & 35.6 & 124 & 36.8 & $335 / 100.0$ \\
\hline Father & 3 & 0.9 & 24 & 7.2 & 35 & 10.4 & 99 & 29.6 & 174 & 51.8 & $335 / 100.0$ \\
\hline \multirow[t]{2}{*}{$\begin{array}{l}\text { Working } \\
\text { status }\end{array}$} & \multicolumn{2}{|c|}{ Unemployment } & \multicolumn{2}{|c|}{ Housewife } & \multicolumn{2}{|c|}{ Retired } & \multicolumn{2}{|c|}{$\begin{array}{c}\text { Works } \\
\text { part-time }\end{array}$} & \multicolumn{2}{|c|}{$\begin{array}{l}\text { Works } \\
\text { full-time }\end{array}$} & Total \\
\hline & $\mathrm{f}$ & $\%$ & $\mathrm{f}$ & $\%$ & $\mathrm{f}$ & $\%$ & $\mathrm{f}$ & $\%$ & $f$ & $\%$ & $\mathrm{f} / \%$ \\
\hline Mother & 26 & 7.8 & 47 & 14.0 & 134 & 40.0 & 16 & 4.8 & 112 & 33.2 & $335 / 100.0$ \\
\hline Father & 21 & 6.3 & - & - & 34 & 10.1 & 19 & 5.7 & 261 & 73.1 & $335 / 100.0$ \\
\hline
\end{tabular}

The outcome of the $t$ test applied to determine whether the students of the sample group had a significant difference in the averages of the total scores of the Internet Total compared to the gender variable, showed significant differences $\left(\mathrm{t}_{(282.89)}=2.260 ; \mathrm{p}<.05\right)$. On the basis of the findings obtained, the average of male students (64.47) is higher than the average scores of female students (58.67) (See Table3).

Table 3. T Test Results According to Gender Variable of Internet Addiction Scale Scores

\begin{tabular}{cccccccl}
\hline & & & & & \multicolumn{3}{c}{$\mathrm{t}$ test } \\
\hline Scales & Group & $\mathrm{N}$ & $\overline{\mathrm{x}}$ & $\mathrm{SD}$ & $\mathrm{T}$ & $\mathrm{df}$ & $\mathrm{p}$ \\
\hline \multirow{2}{*}{ Internet Addiction } & Male & 158 & 64.47 & 26.67 & 2.260 & 282.89 & .025 \\
& Female & 177 & 58.67 & 19.29 & & & \\
\hline
\end{tabular}

As a result of the one-way analysis of variance (ANOVA) conducted to determine whether there was a significant difference in the average of internet addiction scale total scores of the students forming the sample group according to the school achievement (depending on students' perceptions) variable, there were significant differences found between groups' arithmetic averages $(\mathrm{F}=3.349 ; \mathrm{p}<.05)$ (See Table 4) 
Table 4. Results of Variance Analysis of Internet Addiction Scale Scores According to the School Achievement Variable

\begin{tabular}{cccccccccc}
\hline \multicolumn{4}{c}{ Results of ANOVA } & \multicolumn{5}{c}{ F and Sd Values } \\
\hline Group & $N$ & $\overline{\mathrm{x}}$ & $S D$ & & $\begin{array}{c}\text { Sum of } \\
\text { Squares }\end{array}$ & df & $\begin{array}{c}\text { Mean } \\
\text { square }\end{array}$ & $\mathrm{F}$ & $p$ \\
\hline Very good & 39 & 53.46 & 21.74 & Between Groups & 7023.94 & 4 & 1755.98 & 3.349 & 0.011 \\
\hline Good & 162 & 60.48 & 22.54 & Within Groups & 167279.58 & 319 & 524.39 & & \\
Average & 100 & 64,84 & 21.98 & Total & 174303.52 & 323 & & & \\
Bad & 15 & 76.00 & 34.98 & & & & & & \\
Very bad & 8 & 65.00 & 19.18 & & & & & \\
\hline
\end{tabular}

As a result of the Tukey Post-Hoc analysis performed after the variance analysis to determine where the significance difference was among the groups, there was a significant difference in the internet addiction total scores average between the students who stated that their school success was very bad $(\bar{x}=76.00)$ and those who stated that it was very good $(\bar{x}=53.46)$ in favor of those who said that their school success was very bad (See Table 5).

Table 5. The Scale Differences Between Grades According to the Scores Received from the Internet Addiction Scale

\begin{tabular}{|c|c|c|c|c|c|c|}
\hline \multirow[b]{2}{*}{ Dependent Variable } & & \multirow[b]{2}{*}{ Mean Difference (I-J) } & \multirow[b]{2}{*}{ Std. Error } & \multirow[b]{2}{*}{ Sig. } & \multicolumn{2}{|c|}{ 95\% Confidence Interval } \\
\hline & & & & & LowerBound & Upper Bound \\
\hline Internet Total $\mathrm{Bad}$ & Very good & $22.5385^{*}$ & 6.9574 & .035 & .982 & 44.095 \\
\hline
\end{tabular}

One-way ANOVA conducted to determine whether the average of Internet addiction scale total scores of the students of the study group showed a significant difference according to the time period they spared to do homework in one-week period variable, there was a significant difference found between the arithmetic average of the groups $(\mathrm{F}=7.497 ; \mathrm{p}<.05)($ See Table 6$)$.

Table 6. The Results of Variance Analysis of Internet Addiction Scale Scores According to the Variable of the Duration Spared to Do Homework in One-Week Period

\begin{tabular}{|c|c|c|c|c|c|c|c|c|c|c|}
\hline \multicolumn{5}{|c|}{ Results of ANOVA } & \multicolumn{6}{|c|}{$\mathrm{F}$ and $\mathrm{Sd}$ Values } \\
\hline Scale & Group & $N$ & & $S D$ & & $\begin{array}{l}\text { Sum of } \\
\text { squares }\end{array}$ & $\mathrm{Sd}$ & $\begin{array}{l}\text { Mean } \\
\text { Square }\end{array}$ & $\mathrm{F}$ & $p$ \\
\hline \multirow{6}{*}{$\begin{array}{l}\text { Internet } \\
\text { addiction }\end{array}$} & Never & 62 & 74.44 & 28.67 & $\begin{array}{c}\text { Between } \\
\text { Groups }\end{array}$ & 14991.37 & 4 & 3747.84 & 7.497 & 0.000 \\
\hline & 1-2 hours a week & 120 & 59.49 & 21.38 & $\begin{array}{l}\text { Within } \\
\text { Group }\end{array}$ & 164963.42 & 330 & 499.89 & & \\
\hline & 3-5 hours a week & 85 & 60.41 & 21.79 & Total & 179954.79 & 334 & & & \\
\hline & $\begin{array}{l}\text { 6-7 hours a week } \\
\text { hours a week }\end{array}$ & 39 & 56.13 & 18.51 & & & & & & \\
\hline & $\begin{array}{c}8 \text { hours, more a } \\
\text { week }\end{array}$ & 29 & 51.48 & 16.42 & & & & & & \\
\hline & Total & 335 & 61.41 & 23.21 & & & & & & \\
\hline
\end{tabular}

As a result of Tukey Post-Hoc analysis performed after variance analysis to determine where the significant difference was among the groups, there was a significant difference found among the students who said "never" for sparing time to do homework in one-week period $(\bar{x}=74.44)$ and those who said they spared "1-2 hours" ( $\bar{x}=59.44)$, "3-5 hours" ( $\bar{x}=60.41)$, "6-7 hours" $(\bar{x}=56.13)$ and "more than 8 hours" ( $\bar{x}=51.44)$ in favor of those who said never (See Table 7). 
Table 7. The Scale Differences Between Grades According to the Scores Received from the Internet Addiction Scale

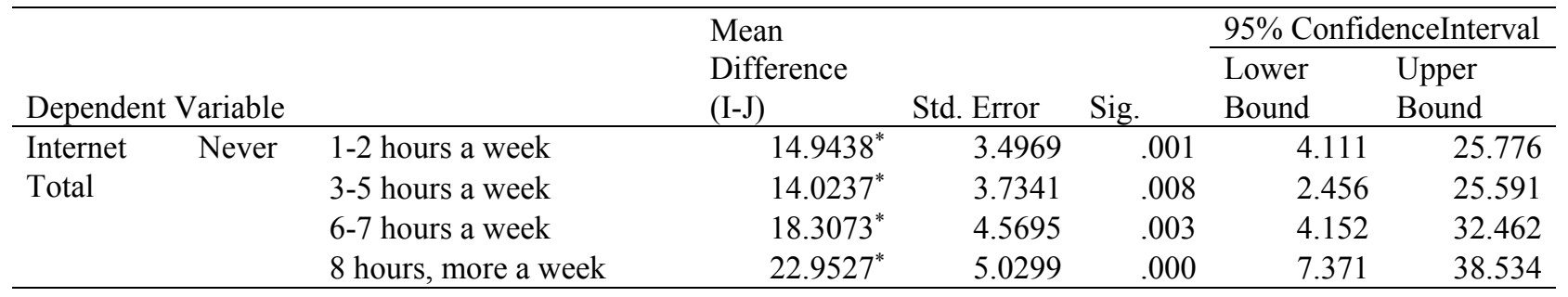

One-way ANOVA conducted to determine whether the average of internet addiction scale total scores of the students of the study group showed a significant difference according to the variable of participating in an activity with their families in one-week period, there was a significant difference found between the arithmetic average of the groups $(\mathrm{F}=6.806 ; \mathrm{p}<.05)($ See Table 8$)$

Table 8. The Results of Variance Analysis of Internet Addiction Scale Scores According to the Variable of Participating in an Activity with Their Families in One-Week Period

\begin{tabular}{|c|c|c|c|c|c|c|c|c|c|c|}
\hline \multicolumn{5}{|c|}{ Results of ANOVA } & \multicolumn{6}{|c|}{ F and Sd Values } \\
\hline Scale & Group & $N$ & $\overline{\mathrm{x}}$ & $S S$ & & $\begin{array}{l}\text { Sum of } \\
\text { Squares }\end{array}$ & $\mathrm{Sd}$ & $\begin{array}{l}\text { Mean } \\
\text { Square }\end{array}$ & $\mathrm{F}$ & $p$ \\
\hline \multirow{6}{*}{$\begin{array}{c}\text { Internet } \\
\text { Total }\end{array}$} & Never & 38 & 76.82 & 30.71 & $\begin{array}{l}\text { Between } \\
\text { Groups }\end{array}$ & 13713.53 & 4 & 3428.38 & 6.806 & 0.000 \\
\hline & $\begin{array}{l}\text { 1-2 hours a } \\
\text { week }\end{array}$ & 74 & 63.57 & 25.26 & $\begin{array}{l}\text { Within } \\
\text { Group }\end{array}$ & 166241.26 & 330 & 503.76 & & \\
\hline & $\begin{array}{l}\text { 3-5 hours a } \\
\text { week }\end{array}$ & 137 & 59.61 & 19.74 & Total & 179954.79 & 334 & & & \\
\hline & $\begin{array}{l}\text { 6-7 hours a } \\
\text { week }\end{array}$ & 45 & 58.84 & 21.31 & & & & & & \\
\hline & $\begin{array}{c}8 \text { hours, more } \\
\text { a week }\end{array}$ & 41 & 52.02 & 17.18 & & & & & & \\
\hline & Total & 335 & 61.41 & 23.21 & & & & & & \\
\hline
\end{tabular}

As a result of Tukey Post-Hoc analysis after variance analysis performed to determine where the significant difference was, there was a significant difference found according to the participation in an activity with the family in one-week period variable among the students who said "never" $(\bar{x}=76.82)$ and those who said "3-5 hours" $(\bar{x}=659.61)$, "6-7 hours" $(\bar{x}=58.84)$ and "more than 8 hours" ( $\bar{x}=52.02)$ in favor of those who said never (SeeTable $9)$.

Table 9. The Scale Differences Between Grades According to the Scores Received from the Internet Addiction Scale

\begin{tabular}{|c|c|c|c|c|c|c|c|}
\hline \multirow{3}{*}{\multicolumn{2}{|c|}{ Dependent Variable }} & & \multirow{2}{*}{$\begin{array}{l}\text { Mean } \\
\text { Difference }\end{array}$} & \multirow[b]{3}{*}{ Std. Error } & \multirow[b]{3}{*}{ Sig. } & \multicolumn{2}{|c|}{ 95\% Confidence Interval } \\
\hline & & & & & & \multicolumn{2}{|l|}{ Lower } \\
\hline & & & $(\mathrm{I}-\mathrm{J})$ & & & Bound & Upper Bound \\
\hline Internet & Never & 3-5 hours a week & $17.2027^{*}$ & 4.1151 & .002 & 4.455 & 29.950 \\
\hline \multirow[t]{2}{*}{ Total } & & 6-7 hours a week & $17.9713^{*}$ & 4.9449 & .011 & 2.653 & 33.289 \\
\hline & & 8 hours, more a week & $24.7914^{*}$ & 5.0541 & .000 & 9.135 & 40.448 \\
\hline
\end{tabular}

One-way ANOVA conducted to determine whether the average of internet addiction scale total scores of the students of the study group showed a significant difference according to the variable of time period they spared for computer games in one-week period, there was a significant difference found between the arithmetic average of the groups $(\mathrm{F}=4.453 ; \mathrm{p}<.05)($ See Table 10$)$. 
Table 10. The Results of Variance Analysis of Internet Addiction Scale Scores According to the Variable of the Time Spared for Computer Games in One-Week Period

\begin{tabular}{|c|c|c|c|c|c|c|c|c|c|c|}
\hline \multicolumn{5}{|c|}{ Results of ANOVA } & \multicolumn{6}{|c|}{$\mathrm{F}$ and $\mathrm{Sd}$ Values } \\
\hline Scale & Group & $N$ & $\overline{\mathrm{x}}$ & $S S$ & & $\begin{array}{l}\text { Sum of } \\
\text { Squares } \\
\end{array}$ & $\mathrm{df}$ & $\begin{array}{l}\text { Mean } \\
\text { Square }\end{array}$ & $\mathrm{F}$ & $p$ \\
\hline \multirow{6}{*}{$\begin{array}{c}\text { Internet } \\
\text { Total }\end{array}$} & Never & 153 & 57.62 & 21.32 & $\begin{array}{c}\text { Between } \\
\text { Groups }\end{array}$ & 9217.51 & 4 & 2304.38 & 4.453 & 0.002 \\
\hline & $\begin{array}{c}\text { 1-2 hours a } \\
\text { week }\end{array}$ & 76 & 60.45 & 24.31 & $\begin{array}{l}\text { Within } \\
\text { Group }\end{array}$ & 170269.58 & 329 & 517.54 & & \\
\hline & $\begin{array}{c}\text { 3-5 hours a } \\
\text { week }\end{array}$ & 35 & 61.11 & 24.21 & Total & 179487.09 & 333 & & & \\
\hline & $\begin{array}{c}\text { 6-7 hours a } \\
\text { week }\end{array}$ & 21 & 64.52 & 20.56 & & & & & & \\
\hline & $\begin{array}{c}8 \text { hours, } \\
\text { more a } \\
\text { week }\end{array}$ & 49 & 73.14 & 24.36 & & & & & & \\
\hline & Total & 334 & 61.34 & 23.22 & & & & & & \\
\hline
\end{tabular}

As a result of Tukey Post-Hoc analysis after variance analysis performed in order to determine where the significant difference was among the groups, there was a significant difference found between the students who indicated that they spared "8 hours and over" ( $\bar{x}=73.14)$ for computer games in one-week period and those who indicated that they do not spare any time "no" ( $\bar{x}=57.62)$ in favor of the students who stated "8 hours and over" per week (See Table $11)$.

Table 11. The Scale Differences Between Grades According to the Scores Received from the Internet Addiction Scale

\begin{tabular}{|c|c|c|c|c|c|c|c|}
\hline & & & Mean & & & $95 \%$ Con & e Interval \\
\hline & Dependent & & $\begin{array}{c}\text { Difference } \\
(\mathrm{I}-\mathrm{J})\end{array}$ & Std. Error & Sig. & $\begin{array}{l}\text { Lower } \\
\text { Bound }\end{array}$ & $\begin{array}{l}\text { Upper } \\
\text { Bound }\end{array}$ \\
\hline $\begin{array}{c}\text { Internet } \\
\text { Addiction } \\
\text { Scale Total }\end{array}$ & $\begin{array}{c}8 \text { hours, } \\
\text { more a } \\
\text { week }\end{array}$ & Never & $15.5219^{*}$ & 3.7342 & .002 & 3.954 & 27.090 \\
\hline
\end{tabular}

As a result of the independent groups $t$ test, applied to determine whether the students of the sample group had a significant difference in the averages of the total scores of the internet addiction according to the variable of availability of internet connection at home, there was a significant difference found $\left(\mathrm{t}_{(22.28)}=4.411 ; \mathrm{p}<.05\right)$. As per the findings obtained, the averages of the students indicating that there is internet connection in their home (Yes $\bar{x}=62.13$ ) were higher than those who stated that there was not (No $\bar{x}=47.29$ ) any internet connection (See Table 12).

Table 12. $T$ Test Results According to the Variable of Availability of Internet Connection at Home of Internet Addiction Scale Scores

\begin{tabular}{lccccccc}
\hline & & & & \multicolumn{3}{c}{$\mathrm{t}$ test } \\
\hline Scale & Groups & $\mathrm{N}$ & $\overline{\mathrm{x}}$ & $\mathrm{SS}$ & $\mathrm{t}$ & $\mathrm{df}$ & $\mathrm{p}$ \\
\hline & YES & 317 & 62.13 & 23.44 & 4.411 & 22.28 & .000 \\
\hline Internet_Total & $\mathrm{NO}$ & 17 & 47.29 & 12.76 & & \\
\hline
\end{tabular}

As a result of the correlation analysis made to determine the relation between the attitudes of the students, who constituted the study group, towards learning and scores on internet addiction behavior characteristics, there was a negative relationship found between attitude towards learning and internet addiction ( $r=-.167$ ) (See Table13). 
Table 13. The Relationship Between Learning Attitude and Internet Addiction

\begin{tabular}{lccc}
\hline & Groups & Attitudes toward learning & Internet Addiction \\
\hline Attitudes toward learning & Pearson Corr. & 1 & $-.167^{* *}$ \\
& Sig.(2-tailed) & & .002 \\
\multirow{2}{*}{ Internet addiction } & & & 335 \\
& Pearson Corr. & $-.167^{* *}$ & 1 \\
& Sig.(2-tailed) & .002 & 335 \\
\hline
\end{tabular}

\section{Discussion}

The results of the research conducted to examine whether there is a relationship between students' attitudes towards learning, academic achievement and internet addictions draw attention to the relationship between the internet addiction and attitude towards learning. The results of the analysis conducted in line with the sub-objectives of the research show that independent variables make a difference in the dependent variables of internet addiction and attitude towards learning.

According to the results of the analysis on whether there is a difference in the internet addiction and attitude towards learning with respect to gender independent variable, while there is a difference in favor of male students in terms of internet addiction, there is no difference in their attitudes towards learning. The findings are in line with the results of the literature related to the game addiction research besides the internet addiction (Ko, Yen, Chen, Chen, \& Yen, 2005; Van Rooij, Ferguson, Van de Mheen, \& Schoenmakers, 2017; King \& Delfabbro, 2016). Accordingly, while some of the results of the studies examining the gender factor in terms of attitudes towards information communication technologies support the relevant data, some of them have revealed different results (Whang, Lee, \& Chang, 2003; Laconi, Tricard, \& Chabrol, 2015; Laconi, S., Kaliszewska-Czeremska, Gnisci, Sergi, Barke, Jeromin, \& Király, 2018). Studies have highlighted that the attitute changes according to the gender regarding the internet technologies and use of internet depend on various factors including having a computer, experiences of computers, school and family environment, cultural and geographcial differences among countries. (Batıgün \& Kılıç, 2011; Bozkurt, Şahin, \& Zoroğlu, 2016; Liang, Zhou, Yuan, Shao, \& Bian, 2016; Morsünbül, 2014; Sargın, 2013; Suri \& Sharma, 2013; Young, 2004). Also researches emphasize that the levels of utilization of social environmental resources such as expectations of social roles for men and women and the periods of development in which they began to benefit from these resources may vary depending on the dynamics of social life of men and women (Marino, Vieno, Pastore, Albery, Frings, \& Spada, 2016). Research findings on socio-psychological dynamics, family roles and duties of Turkish society reveal that the expectations of male and female gender identity role behaviors can make a difference in the way they are raised. The fact that there is no difference in the attitudes of students towards learning according with respect to gender variable indicates some degree of difference with the studies related to academic achievement. Research shows that learning motivation, academic achievement levels, anxiety about academic achievement and school burnout in female students are higher than in male students. Interdisciplinary studies emphasize that social fabric and consequently domestic dynamics have different effects on the living spaces of men and women in the process of identity acquisition. If there are no differences in attitudes toward learning with respect to gender in this research, this can be explained with the fact that the students participated in this study are the students at the schools with a high level of academic success in the transition from secondary education to high school and from high school to the university in Turkey. In order to be able to study in these high schools, students need to get a high score in the transition from secondary to high school, which includes boarding schools for students from different regions of Turkey. In addition, the schools in which the research was conducted were randomly selected among the schools with similar characteristics in the district of Kadiköy, Istanbul for the main purpose of the research. In other words, the academic achievement of the students of these schools cannot only be evaluated with the exam preparation process at 8th grade, and the motivation for learning should also be different from other students in the previous education levels. When the demographic information of the parents of the study group are taken into consideration, if a majority of them are high-school or university graduates or whether they are working mothers or retired affect the distinctions in the attitudes towards learning. The literature on psychology, education and learning psychology stress that the competencies of the individuals' being able to manage their own learning develops in accordance with their experiences and that the family plays an important role during this period (Effeney, Carroll, \& Bahr, 2013; Leung, 2006; Kapıkıran \& Özgüngör, 2009; Peker \& Kağımanlı, 2018; Üneri \& Tandır, 2011; Y1lmaz, 2014). While the concepts of self-efficacy, self-regulation, focus of control in the literature related to academic achievement and competence assign the individual's self-improvement responsibility to him/her, they also 
draw attention to the relationship of the process with social and emotional environment (Pajares \& Schunk, 2001; Bong \& Skaalvik, 2003; Bandura, 2005). From past to present, the fact that meditation for problem solving may be more effective than the things taught at school has been emphasized in several studies and this process could also be influential on the young being unsuccesful at schools (Rand, Tannenbaum, \& Feuerstein, 1979) and it could create a positive effect on the academic achievement and learning habits by the controller and disciplined behaviors of the family (Pressman, Owens, Evans, \& Nemon 2014). Therefore, although it is perceived that it does not comply with the literature as no difference between the female and male students was found in terms of attitudes towards learning, the characteristics of the student group should be considered in the evaluation of the findings.

According to the independent variables of students' school performance (according to their own expressions) and the time (duration) they spend doing homework and playing computer games in one week period, findings on whether there is a difference in attitudes towards learning and internet addiction indicate that there are no differences in their attitudes towards learning, in addition mean scores of internet addiction change in favor of the students who stated that their academic success is bad, the students who stated that they "never" spend time to do homework, and those who stated that they devoted more time to computer games. This finding is in line with the finding which displays that there is a negative relationship between learning attitudes and internet addiction behaviors of the sample group. These findings support the hypothesis, which is the main purpose of the study, that learning attitudes can make a difference in the behaviors of internet addiction resulting from the use of information technologies other than its real purpose. In addition, the literature on internet addiction in recent years argues that, it is necessary to differentiate these dynamics by emphasizing that the increasing use of information technologies applications in education, training and business world in order to learn and develop as a requirement of information society cannot be considered within the scope of internet addiction (Griffiths, Kuss, Billieux, \& Pontes, 2016) Therefore, students' use of information technology applications while doing homework or studying is not discussed in the context of internet addiction, on the contrary, it is regarded as the role behavior supporting the learning process of the member of information society. On the other hand, the difference in terms of internet addiction of students who stated that they do not take time to do homework, students who evaluate their academic success as bad and students who stated that they play computer games, can be supported with research related to adolescence behavior and adaptation problems as well as literature related to internet addiction and game addiction (Baltacı \& Akpınar, 2011; Drennan, Kennedy, \& Pisarski, 2005; Işı1k, 2010; Tandoğan \& Orhan, 2007; Wu, 2013; Vigna-Taglianti, Brambilla, Priotto, Angelino, Cuomo, \& Diecidue, 2017).

Considering the other outcomes of the research, spending time with the family is significant for the students and can differentiate the Internet addiction behavior. According to the finding obtained, there has been a significant difference in terms of Internet addiction behaviour in favor of the students stating that they have "never" spared time for any activity with their parents in a week compared to the students sparing time for activities with their parents. In addition, when compared to those who do not have internet connections at home to those that do, there is a difference in terms of Internet addiction in favor of the students who have Internet connection at home. Both findings stress the significance of inter-family relationships. The finding points out the importance of the inter-family communication and interaction for the students (adolescents) and it suggests that the direction of the virtual environment activities of the students may vary as the quality and quantity of family relationships show distinction (Chen, Chen, \& Gau, 2015; Lachmann, Sariyska, Kannen, Cooper, \& Montag, 2016; Bonnaire \& Phan, 2017; Seyrek, Cop, Sinir, Ugurlu, \& Şenel, 2017)

The results of the correlation analysis conducted in line with the main purpose of the research show that there is a negative relationship between the attitude towards learning and internet addiction. The obtained finding supports the starting point, the idea, of the research, which is, the difference in the problem of internet addiction behavior among students with different attitudes towards learning. Additionally, in the related literature, it is seen that studies on the relationship between academic achievement and internet addiction have reached similar results (Siddiqui, Memon, \& Siddiqui, 2016; Badri, Al Nuaimi, Guang, \& Al Rashedi, 2017). Related studies indicate that many dynamics ranging from personality traits to familial factors can be effective in internet addiction behavior (Johnson, 2016). Therefore, although the degree of negative relationship between related features is not as high as expected, it is thought that this finding may contribute to the studies on the prevention of internet addiction. The finding suggests that information technologies can be used in accordance with their purposes with the effectiveness of learning processes and applications in the stages of education. In addition, when we consider that the applications of information technologies such as games and social networking that support addictive behavior problems serve different needs of individuals; in case that the students develop behaviors towards meeting their psycho-social needs, information technologies may become a means of improving quality of life rather than being a problem. 


\section{Conclusion}

As a result of this study, which is designed to examine whether there is a relationship between students' attitudes towards learning, academic achievement and internet addictions, whereas a negative relationship between students' internet addiction and attitudes towards learning was found, it is observed that the internet addiction scores of the students who perceive their academic performance as high and devote more time to do homework were low. The findings show that as the attitudes towards learning differ, there may be a decrease in internet addiction behaviour.

According to the results of the study, there is a difference with respect to gender variable in favour of male students, and according to the variables of playing computer games, having an activity with the family and having an internet connection at home in favour of the students who were more likely to play computer games, spend less time in a week with his family and have internet connection at home in terms of internet addiction. However, the findings also show that there were no differences in students' attitudes towards learning regarding the related variables.

Considering to the research findings, it is possible to express that differentiation of students' attitudes towards learning can support effective and efficient use of information technologies and that the negative differentiation of the attitudes towards learning can generate Internet addiction as a result of inefficient use of the information technologies.

\section{Recomendations}

According to the results of this research as a relational screening model aimed at determining whether there has been a relationship between the students' attitudes towards learning, academic achievement and Internet addiction, it is believed that the dynamics that can make a difference in the attitudes of the students towards learning should be discussed multidimensionally. It is clearly observed that in the educational process, information technology fails to be sufficient in changing the motivation of the students to learn, and that this situation causes certain problems related to the use of such technologies. It is stated that establishing effective communication networks in the contexts of administrators, teachers and the family and putting the learning process out of the performance-based and exam-oriented understanding have an importance considering the student as a "human" in the education environment. In particular, it is necessary to strengthen the leadership and guidance duties of teachers for the students to become technologically literate.

Due to certain negativities that have been observed and experienced during the initial and application phase of this research, some modifications in the scope of the research have been done. The research has been initially designed to examine the teachers' attitudes towards learning as well as the students' attitudes, the relationship between their academic achievement and Internet addiction. Due to the fact that data could be obtained from 40 teachers from the schools where students of the study group attended, attitudes of teachers towards learning were to be excluded. On account of the work load of the teachers or of different factors, it has not been possible to collect information on their attitudes towards learning. One of the issues that the researcher has observed during the applications in different studies is related to the significance of the contributions of the scientific studies on teaching to the teaching process and to the teachers themselves, rather than the occupational burnout of the teachers. Therefore, it is recommended that the in-service educational process of the teachers should be revised and regulated accordingly. Moreover, it is stated that it is necessary to prevent the aforementioned training events from generating "inadequacy perception" and to emphasize the importance of the teacher as well as the school administrators, students and parents.

\section{References}

Ağır, Ahmet \& Bayraktar Mutlu, Duygu. (2011). Web 2.0 Araçlarının Eğitim Fakültesi Öğrencileri Tarafından Benimsenme Durumu Web Günlükleri Örneği. 11th International Educational Technology Conference (IETC2011), Istanbul, Turkey. 2098-2102.

Ağır, Ahmet. (2007). Bilişim Toplumuna Geçis Sürecinde Bilgi Yönetimi Yaklaşımı. Istanbul Üniversitesi Iletişim Fakültesi Dergisi, 1(30), 1-18.

Ağır, Ahmet. (2014). What Are The Usage Conditions of Web 20 Tools Faculty of Education Students. Turkish Online Journal of Distance Education, 15(3), 171-196. https://doi.org/10.17718/tojde.91465

Ajzen, I., \& Fishbein, M. (1977). Attitude-behavior relations: A theoretical analysis and review of empirical research. Psychological Bulletin, 84(5), 888-918. http://dx.doi.org/10.1037/0033-2909.84.5.888

Ajzen, I., \& Fishbein, M. (2005). The influence of attitudes on behavior. The handbook of attitudes, 173(221), 31. 
Akolaş, D. A. (2004). Bilişi̧im sistemleri ve bilişim teknolojisinin küreselleşme olgusu ve girişimcilik üzerine yansımaları. Selçuk Üniversitesi Sosyal Bilimler Enstitüsü Dergisi, 12, 29-43.

Allport, Gordon W. (1967). Pattern and Growth in Personality. Oxford, England: Holt, Reinhart \& Winston.

Anderson, E. L., Steen, E., \& Stavropoulos, V. (2017). Internet use and Problematic Internet Use: A systematic review of longitudinal research trends in adolescence and emergent adulthood. International Journal of Adolescence and Youth, 22(4), 430-454. https://doi.org/10.1080/02673843.2016.1227716

Ayas, T., Çakır, Ö., \& Horzum, M. B. (2011). Ergenler için bilgisayar bağımlılığı ölçeği. Kastamonu Eğitim Dergisi, 19(2), 439-448.

Badri, M., Al Nuaimi, A., Guang, Y., \& Al Rashedi, A. (2017). School performance, social networking effects, and learning of school children: Evidence of reciprocal relationships in Abu Dhabi. Telematics and Informatics, 34(8), 1433-1444. https://doi.org/10.1016/j.tele.2017.06.006

Baltacı, M., \& Akpınar, B. (2011). Web tabanlı öğretimin öğrenenlerin üstbiliş farkındalık düzeyine etkisi/the effect of web based instruction on the metacognition awareness levels of learners. Mustafa Kemal Üniversitesi Sosyal Bilimler Enstitüsü Dergisi, 8(16), 319-333.

Bandura, A. (2005). Adolescence development from an agentic perspective. In Tim Urdan and Frank Pajares (Eds.), Self Efficacy Beliefs of Adolescence (1-47). USA: Information Age Publishing.

Batıgün, A. D., \& Kılı̧̧, N. (2011). Internet bağımlılı̆̆ı ile kişilik özellikleri, sosyal destek, psikolojik belirtiler ve bazı sosyo-demografik değişkenler arasındaki ilişkiler. Türk Psikoloji Dergisi, 26(67), 1-10.

Bilgin, N. (2007). Sosyal Psikoloji Sözlüğ̈̈ Kavramlar ve Yaklaşımlar. İstanbul: Bağlam Yayınevi.

Bong, M., \& Skaalvik, E. M. (2003). Academic self-concept and self-efficacy: How different are they really?. Educational Psychology Review, 15(1), 1-40.

Bonnaire, C., \& Phan, O. (2017). Relationships between parental attitudes, family functioning and Internet gaming disorder in adolescents attending school. Psychiatry Research, 255, 104-110. https://doi.org/10.1016/j.psychres.2017.05.030

Bozkurt, H., Şahin, S., \& Zoroğlu, S. (2016). İnternet bağımlılığı: Güncel bir gözden geçirme. Journal Of Contemporary Medicine, 6(2), 1-13.

Buabeng-Andoh, C. (2012). Factors Influencing Teachers' Adoption and Integration of Information and Communication Technology into Teaching: A Review of the Literature. International Journal of Education and Development Using Information and Communication Technology, 8(1), 136-155.

Castells, M. (1997). An introduction to the information age. City, 2(7), 6-16.

Castells, M. (2011). The rise of the network society. NewYork: John Wiley \& Sons.

Castells, M. (2013). Communication power. Oxford: Oxford University Press.

Chen, Y. L., Chen, S. H., \& Gau, S. S. F. (2015). ADHD and autistic traits, family function, parenting style, and social adjustment for Internet addiction among children and adolescents in Taiwan: A longitudinal study. Research in Developmental Disabilities, 39, 20-31. https://doi.org/10.1016/j.ridd.2014.12.025

Cole, H., \& Griffiths, M. D. (2007). Social interactions in massively multiplayer online role-playing gamers. Cyberpsychology \& behavior, 10(4), 575-583. https://doi.org/10.1089/cpb.2007.9988

Deperlioğlu, Ö., \& Köse, U. (2010). Web 2.0 teknolojilerinin eğitim üzerindeki etkileri ve örnek bir öğrenme yaşantısı. Akademik Bilişim, Istanbul, Turkey. 10-12.

Drennan, J., Kennedy, J., \& Pisarski, A. (2005). Factors affecting student attitudes toward flexible online learning in management education. The Journal of Educational Research, 98(6), 331-338. https://doi.org/10.3200/JOER.98.6.331-338

Effeney, G., Carroll, A., \& Bahr, N. (2013). Self-regulated learning: Key strategies and their sources in a sample of adolescent males. Australian Journal of Educational and Developmental Psychology, 13, 58-74.

Fazio, R. H. (1986). How do attitudes guide behavior. Handbook of motivation and cognition: Foundations of social behavior, 1, 204-243.

Fishbein, M. (1967). A consideration of beliefs, and their role in attitude measurement. In M. Fishbein (Ed.), Readings in attitude theory and measurement (pp. 257-266). New York: John Wiley \& Sons 
Glynn, S. M., Aultman, L. P., \& Owens, A. M. (2005). Motivation to learn in general education programs. The Journal of General Education, 150-170.

Greenwald, A. G. (1968). Cognitive learning, cognitive response to persuasion, and attitude change. Psychological

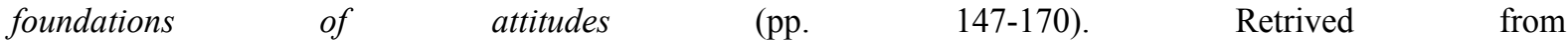
http://citeseerx.ist.psu.edu/viewdoc/download?doi=10.1.1.19.7121\&rep=rep1\&type=pdf

Griffiths, M. (2000). Internet addiction-time to be taken seriously? Addiction research, 8(5), 413-418.

Griffiths, M. D., Kuss, D. J., Billieux, J., \& Pontes, H. M. (2016). The evolution of Internet addiction: A global perspective. Addictive Behaviors, 53, 193-195. https://doi.org/10.1016/j.addbeh.2015.11.001

Günüç, S., \& Kayri, M. (2010). Türkiye'de internet bağımlılık profili ve internet bağımlılık ölçeğinin geliştirilmesi: Geçerlik-güvenirlik çalışması. Hacettepe Üniversitesi Eğitim Fakültesi Dergisi, 39(39).

Hong, K. S., Ridzuan, A. A., \& Kuek, M. K. (2003). Students' attitudes toward the use of the Internet for learning: A study at a university in Malaysia. Educational Technology \& Society, 6(2), 45-49.

Hong-sheng, W. A. P. (2005). A Research on the Relationship Between Learning Anxiety, Learning Attitude, Motivation and Test Performance. Psychological Development and Education, 1.

Işık, A. D. (2010). Bilişim teknolojileri dersi için oluşturmacı yaklaşım doğrultusunda hazırlanan öğrenme paketinin etkileri (Doctoral dissertation), DEÜ Eğitim Bilimleri Enstitüsü. Retrieved from https://dspace.deu.edu.tr/xmlui/handle/12345/6807

Isman, A., \& Gungoren, O. C. (2013). Being digital citizen. Procedia-Social and Behavioral Sciences, 106, $551-556$. https://doi.org/10.1016/j.sbspro.2013.12.063

Johnson, N. F. (2016). The multiplicities of internet addiction: The misrecognition of leisure and learning. Routledge. https://doi.org/10.4324/9781315555430

Kapıkıran, Ş., \& Özgüngör, S. (2009). Ergenlerin sosyal destek düzeylerinin akademik başarı ve güdülenme düzeyi ile ilişkileri. Çocuk ve Gençlik Ruh Să̆liğı Dergisi, 16(1), 21-30.

Kara, A. (2010). Öğrenmeye ilişkin tutum ölçeğinin geliştirilmesi. Elektronik Sosyal Bilimler Dergisi, 9(32), 49-62.

Karasar, N. (2014). Bilimsel Araştırma Yöntemi. Ankara: Nobel Yayınları.

Kettanurak, V. N., Ramamurthy, K., \& Haseman, W. D. (2001). User attitude as a mediator of learning performance improvement in an interactive multimedia environment: an empirical investigation of the degree of interactivity and learning styles. International Journal of Human-Computer Studies, 54(4), 541-583.

Kim, H. R., Choi, E. Y., Kang, H. Y., \& Kim, S. M. (2011). The relationship among learning satisfaction, learning attitude, self-efficacy and the nursing students academic achievement after simulation-based education on emergency nursing care. The Journal of Korean Academic Society of Nursing Education, 17(1), 5-13.

Kim, J., LaRose, R., \& Peng, W. (2009). Loneliness as the cause and the effect of problematic Internet use: The relationship between Internet use and psychological well-being. CyberPsychology \& Behavior, 12(4), 451-455.

King, D. L., \& Delfabbro, P. H. (2016). The Cognitive Psychopathology of Internet Gaming Disorder in Adolescence. J Abnorm Child Psychol, 44(8), 1635-1645. https://doi.org/10.1007/s10802-016-0135-y

Ko, C. H., Yen, J. Y., Chen, C. C., Chen, S. H., \& Yen, C. F. (2005). Gender differences and related factors affecting online gaming addiction among Taiwanese adolescents. The Journal of nervous and mental disease, 193(4), 273-277. https://doi.org/10.1097/01.nmd.0000158373.85150.57

Kocacık, F. (2003). Bilgi toplumu ve Türkiye. CÜ Sosyal Bilimler Dergisi, 27(1), 1-10.

Kuss, D. J., Van Rooij, A. J., Shorter, G. W., Griffiths, M. D., \& de Mheen, D. (2013). Internet addiction in adolescents: Prevalence and risk factors. Computers in Human Behavior, 29(5), 1987-1996.

Kwon, J. H. (2011). Toward the prevention of adolescent Internet addiction. Internet addiction: a handbook and guide to evaluation and treatment. New Jersey: Wiley, 223-44.

Lachmann, B., Sariyska, R., Kannen, C., Cooper, A., \& Montag, C. (2016). Life satisfaction and problematic Internet use: Evidence for gender specific effects. Psychiatry research, 238, 363-367. https://doi.org/10.1016/j.psychres.2016.02.017 
Laconi, S., Kaliszewska-Czeremska, K., Gnisci, A., Sergi, I., Barke, A., Jeromin, F., ... \& Király, O. (2018). Cross-cultural study of Problematic Internet Use in nine European countries. Computers in Human Behavior, 84, 430-440. https://doi.org/10.1016/j.chb.2018.03.020

Laconi, S., Tricard, N., \& Chabrol, H. (2015). Differences between specific and generalized problematic Internet uses according to gender, age, time spent online and psychopathological symptoms. Computers in Human Behavior, 48, 236-244. https://doi.org/10.1016/j.chb.2015.02.006

Leung, L. (2006). Stressful life events, motives for Internet use, and social support among digital kids. CyberPsychology \& Behavior, 10(2), 204-214.

Liang, L., Zhou, D., Yuan, C., Shao, A., \& Bian, Y. (2016). Gender differences in the relationship between internet addiction and depression: A cross-lagged study in Chinese adolescents. Computers in Human Behavior, 63, 463-470.

Lyvers, M., Karantonis, J., Edwards, M. S., \& Thorberg, F. A. (2016). Traits associated with internet addiction in young adults: Potential risk factors. Addictive behaviors reports, 3, 56-60. https://doi.org/10.1016/j.abrep.2016.04.001

Marino, C., Vieno, A., Pastore, M., Albery, I. P., Frings, D., \& Spada, M. M. (2016). Modeling the contribution of personality, social identity and social norms to problematic Facebook use in adolescents. Addictive behaviors, 63, 51-56. https://doi.org/10.1016/j.addbeh.2016.07.001

McAuley, J., Leskovec, J., \& Jurafsky, D. (2012, December). Learning attitudes and attributes from multi-aspect reviews. In 2012 IEEE 12th International Conference on Data Mining (pp. 1020-1025). IEEE. https://doi.org/10.1109/icdm.2012.110

Mehroof, M., \& Griffiths, M. D. (2010). Online gaming addiction: the role of sensation seeking, self-control, neuroticism, aggression, state anxiety, and trait anxiety. Cyberpsychology, behavior, and social networking, 13(3), 313-316. https://doi.org/10.1089/cyber.2009.0229

Morsünbül, Ü. (2014). Internet addiction in adolescence period: its relations with identy style and ruminative exploration. Anatolian Journal of Psychiatry, 15(1), 77-83. https://doi.org/10.5455/apd.43504

Olson, J. M., \& Zanna, M. P. (1993). Attitudes and attitude change. Annual review of psychology, 44(1), 117-154. https://doi.org/10.1146/annurev.ps.44.020193.001001

Osborne, J., Simon, S., \& Collins, S. (2003). Attitudes towards science: A review of the literature and its implications. International journal of science education, 25(9), 1049-1079. https://doi.org/10.1080/0950069032000032199

Pajares, F., \& Schunk, D. (2001). The development of academic self-efficacy. Development of Achievement Motivation. United States, 7.

Peker, A., \& Kağızmanlı, N. (2018). Ebeveyn tutumlarının ergenlerin akademik güdülenme düzeyleri üzerindeki yorday1c1 etkisi. Mersin University Journal of the Faculty of Education, 14(1), 210-224. https://doi.org/10.17860/mersinefd.338252

Pressman, R. M., Owens, J. A., Evans, A. S., \& Nemon, M. L. (2014). Examining the interface of family and personal traits, media, and academic imperatives using the learning habit study. The American Journal of Family Therapy, 42(5), 347-363. https://doi.org/10.1080/01926187.2014.935684

Rahimi, M., \& Yadollahi, S. (2011). Foreign language learning attitude as a predictor of attitudes towards computer-assisted language learning. Procedia Computer Science, 3, 167-174. https://doi.org/10.1016/j.procs.2010.12.029

Rand, Y. A., Tannenbaum, A. J., \& Feuerstein, R. (1979). Effects of Instrumental Enrichment on the psychoeducational development of low-functioning adolescents. Journal of Educational Psychology, 71(6), 751. http://dx.doi.org/10.1037/0022-0663.71.6.751

Richardson, V. (1996). The role of attitudes and beliefs in learning to teach. Handbook of research on teacher education, 2, 102-119.

Sargın, N. (2013). Üniversite öğrencilerinin internete yönelik tutumları ve problemli internet kullanımları. Turkish Journal of Education, 2(2), 44-53. https://doi.org/10.19128/turje.181059

Scardamalia, M., \& Bereiter, C. (1994). Computer support for knowledge-building communities. The journal of the 
learning sciences, 3(3), 265-283. https://doi.org/10.1207/s15327809jls0303_3

Seferoğlu, S. S. (2004). Öğretmen yeterlilikleri ve mesleki gelişim. Bilim ve Aklın Aydınlı̆̆ında Eğitim, 58, 40-45.

Seyrek, S., Cop, E., Sinir, H., Ugurlu, M., \& Şenel, S. (2017). Factors associated with Internet addiction: Cross-sectional study of Turkish adolescents. Pediatrics international, 59(2), 218-222. https://doi.org/10.1111/ped.13117

Siddiqui, S. B., Memon, N., \& Siddiqui, F. (2016). The Relationship Between Internet Addiction And Study Habits Of University Undergraduates. Grassroots, 50(1).

Suri, G., \& Sharma, S. (2013). The impact of gender on attitude towards computer technology and e-learning: An exploratory study of Punjab University, India. International Journal of Engineering Research, 2(2), 132-136.

Tandogan, R. O., \& Orhan, A. (2007). The Effects of Problem-Based Active Learning in Science Education on Students' Academic Achievement, Attitude and Concept Learning. Online Submission, 3(1), 71-81. https://doi.org/10.12973/ejmste/75375

Tinkham, T. (1989). Rote learning, attitudes, and abilities: A comparison of Japanese and American students. TESOL Quarterly, 23(4), 695-698. https://doi.org/10.2307/3587547

Toffler, A. (1981). Education and the Future: An Interview with Alvin Toffler. Social Education, 45(6), 422-26.

Üneri, Ö. Ş., \& Tanıdır, C. (2011). Evaluation of internet addiction in a group of high school students: a cross-sectional study. Düşünen Adam: The Journal of Psychiatry and Neurological Sciences, 24(4), 265-272.

Van Merriënboer, J. J., \& Brand-Gruwel, S. (2005). The pedagogical use of information and communication technology in education: a Dutch perspective. Computers in Human Behavior, 21(3), 407-415. https://doi.org/10.1016/j.chb.2004.10.004

Van Rooij, A. J., Ferguson, C. J., Van de Mheen, D., \& Schoenmakers, T. M. (2017). Time to abandon Internet Addiction? Predicting problematic Internet, game, and social media use from psychosocial well-being and application use. Clinical Neuropsychiatry, 14(1), 113-121.

Vigna-Taglianti, F., Brambilla, R., Priotto, B., Angelino, R., Cuomo, G., \& Diecidue, R. (2017). Problematic internet use among high school students: Prevalence, associated factors and gender differences. Psychiatry research, 257, 163-171. https://doi.org/10.1016/j.psychres.2017.07.039

Whang, L. S. M., Lee, S., \& Chang, G. (2003). Internet over-users' psychological profiles: a behavior sampling analysis on internet addiction. Cyberpsychology \& behavior, 6(2), 143-150. https://doi.org/10.1089/109493103321640338

Williams, E. (1992). Student attitudes towards approaches to learning and assessment. Assessment and evaluation in higher education, 17(1), 45-58. https://doi.org/10.1080/0260293920170105

Wu, C. F. (2013). Learning attitude and its effect on applying cloud computing service to IT education. International Journal of u-and e-Service, Science and Technology, 6(1), 39-48.

Yen, C. F., Ko, C. H., Yen, J. Y., Chang, Y. P., \& Cheng, C. P. (2009). Multi-dimensional discriminative factors for Internet addiction among adolescents regarding gender and age. Psychiatry and clinical neurosciences, 63(3), 357-364. https://doi.org/10.1111/j.1440-1819.2009.01969.x

Yılmaz, F. (2014). Ortaokul 6.7. 8. sinıf ögrencilerinin algılanan ebeveyn tutumlart ile sosyal duygusal ögrenme becerileri arasindaki ilişkinin incelenmesi (Master's thesis). İstanbul Arel Üniversitesi Sosyal Bilimler Enstitüsü. Retrieved from https://hdl.handle.net/20.500.12294/152

Yılmaz, K., \& Horzum, M. B. (2005). Küreselleşme, bilgi teknolojileri ve üniversite. İnönü Üniversitesi Eğitim Fakültesi Dergisi, 6(10), 103-121.

Young, K. S. (1998). Internet addiction: The emergence of a new clinical disorder. Cyberpsychology \& behavior, 1(3), 237-244. https://doi.org/10.1089/cpb.1998.1.237

Young, K. S. (2004). Internet addiction: A new clinical phenomenon and its consequences. American behavioral scientist, 48(4), 402-415. https://doi.org/10.1177/0002764204270278 